\title{
The role of youth in water source manage- ment in Tanzania: experience of villages in the Great Ruaha River, Iringa District
}

\author{
Norbert J. Ngowi (1), Elizabeth L. Genda (1), \\ Adelaide E. Sallema (2) \\ (I) Institute of Development Studies, Mzumbe University, Tanzania \\ (2) Museum and House of Culture, National Museum of Tanzania, Tanzania
}

\begin{abstract}
Youth refers to the young active human resources which in 2012 constituted about $34.7 \%$ of the total population of Tanzania. However, there is a paucity of information on the role of youth in the management of water resources in the majority of the rural areas. This paper draws on the experience of the conceptual framework for water governance at the local level. The study examines the role of youth in water source management as it draws on strategies for water management in Kihanga and Migoli Villages located adjacent the Great Ruaha River of Iringa District. The Great Ruaha River covers $47 \%$ of the largest Rufiji Basin in Tanzania. A questionnaire was used to collect data from I6r youths within the surveyed households. In-depth interviews with 5 key informants and focus group(s) of 50 participants were used to supplement data that could not be obtained through surveys. The results show that $59.6 \%$ of respondents were not involved in the Water Committee activities. Patrolling the sources and fetching water at night are among the major strategies used in the management of water sources and supply at least in the short term. These findings together with methods used could be replicated in other areas as they provide opportunities for the study of water governance at the local level. The study recommends the integration of young people into water committees and the establishment of water pumping stations at a suitable distance from Mtera dam to reduce degradation.
\end{abstract}

Key words: Flemish, water source management, governance, Great Ruaha, institutions, vinyungu

\section{Introduction}

Rivers provide water to most of the rural communities in Africa (estimated to be $75 \%$ ) $70 \%$ of which are involved in agriculture, the main source of livelihood (Water Research Commission (WRC), 2005). The WRC (2005) indicates that human demand for water has determined the practices of managing water in many areas. The shortage of water was seen to limit agricultural production, domestic use and industrial development in most African countries (WRC, 2005). The Ministry of Water and Irrigation in Tanzania (United Republic of Tanzania-URT, 20Io) estimated the availability of fresh water to reach about $2,300 \mathrm{~m}^{3} /$ capita/year. This ratio is above the United Nations (UN) categorization 
( $\mathrm{I}, 700 \mathrm{~m}^{3} /$ capita/year for water pressure and or $\mathrm{I}, 000 \mathrm{~m}^{3} /$ capita/year for water scarcity). However, it is projected that the annual renewal rate will drop to $\mathrm{I}, 500 \mathrm{~m}^{3} /$ capita/year by 2025 due human population growth alone (United Republic of Tanzania (URT), 20Io).

The Great Ruaha River (GRR) of Tanzania supports irrigated agriculture including the famous valley bottom cultivation plots or vinyungu as they are known locally (Magembe, 2007). It is also essential to wildlife-based tourism in the Ruaha National Park, fisheries and hydropower production in Mtera dam. Grazing is another major livelihood activity conducted alongside the GRR (Sosovele and Ngwale, 2002). Given the services that the GRR provides, any indication of deprivation, would be a sufficient reason to seek different ways to address the problem (Ministry of Natural Resources and Tourism (MNRT), 2007).

Different people and institutions define youth differently. The Commonwealth Youth Programme defines youth as individuals aged between 15 and 29 (Lekunze, 200I). In Tanzania, youth is any person aged between 15 and 24 years (URT, 2007). However, this study adopts the more frequently used country-specific definition of a person aged between 15 and 34 years (UN, 2015; URT, 2007). By 2010 about $80 \%$ of young people in the world were found in Africa and about $20 \%$ of these were young people aged between 15 and 24 (UNICEF, 20II). Lekunze (200I) shows that those below the age of 30 constitute about $55 \%$ and in Commonwealth countries make up around $15 \%$ and $35 \%$ of the population. In 20I2, of Tanzania's total population $44.8 \%$ were children aged o to I7 years and $34.7 \%$ were youth aged 15 to 35 years (National Bureau of Statistics (NBS), 20I4). The World Bank states that $20 \%$ of the population or about 200 million people in Africa hold great potential for economic growth through participation in labour markets and as consumers (Agbor et al., 20I2). A young population can be a resource that supports governance reforms. However, a large youth population that is not fully absorbed into employment can also be a liability, undermining growth prospects (Agbor et al., 2012).

Khedun (2012) and Lekunze (200I) suggest that youth have great potential for enhancing water governance because of their size in numbers that could offer an important labour force, reasoning power, writing skills, and networking. However, despite this potential, youth, like other social groups (women, indigenous groups and elderly), face an unequal distribution of assets, power relations, and they depend on the elderly or elite groups even though these elites may be responsible for the continuing oppression of the youth (Lekunze, 200I). These critiques suggest that, even after more than two decades of Integrated Water Resources Management (IWRM), water sources are being lost in the GRR of Tanzania due to several factors, including: institutional arrangements, poor governance, increased human and livestock population, high rates of evaporation and water abstraction rates (Rufiji Basin Water Board (RBWB), 2015; Rufiji Basin Water Office (RBWO), 20II; Sokile et al., 2003; Stockholm Environment Institute (SEI), 20II; MNRT and Ministry of Foreign Affairs Denmark, 2003; Sustainable Management of the Usangu Wetland and its Catchment (SMUWC), 200I). Different studies have been conducted on the degradation of water sources in the GRR (Iringa District Council, 2013; RBWO, 20II; Sokile et al., 2005) Nevertheless, information on youth involvement in the management 
of water sources in most of the rural areas is either under-reported or lacking altogether. It is against this background that this article, examines the role of youth in conserving water sources in and around Kihanga and Migoli Villages in Iringa District, Tanzania. Understanding of the role of youth is a significant step towards the development of appropriate techniques for policy decisions. This study aims to answer the following questions:

i. What is the role of youth in water source management?

ii. What are the strategies used in the management of water sources?

This article is divided into four sections. The first two concern water resources management, youth and the theoretical framework guiding this work. The third section describes the study area, sample selection, methods used in data collection, analysis and the study limitations. The fourth section describes results and discussion. The final section presents conclusion of the study.

\section{Theoretical framework}

About $50 \%$ of the population in Sub-Saharan Africa is under I8 years (UNFPA, 20I5). That population will become even younger in the 2015-2020 period. The size of the youth population cohort, the productive resources it possesses and its activities call for the need to involve young people as actors in water resources within the context of IWRM (Dungumaro and Madulu, 2003; Lekunze, 200I; Logo et al., 20I4; Movik et al., 20I6). Theoretically, youth have great potential for enhancing water governance. Because of their population size they make up an important labour force, constitute considerable reasoning power, writing skills, and high levels of networking (Khedun, 2012; Lekunze, 200I) although some of these are questionable.

The different parts of the world witnessed the involvement of different stakeholders in water management through IWRM (Akkerman and Witter, 2013; Dungumaro and Madulu, 2003; Movik et al., 2016; Sokile et al., 2003). Examples of the programs that have involved youth include the community water projects in Cameroon (Lekunze, 200I). In Tanzania, community participation in water management through IWRM started in therggos (Sokile et al., 2003) but the level of their involvement has been low due to lack of public trust (Dungumaro and Madulu, 2003), and this might lead to aggression among water users due to conflicting interests. The water policy of Tanzania (2002) recognized community participation in the water resource management.

A conceptual framework for water governance (Figure I) that is adopted in this study has been modified from Franks et al., 2013. Before giving a description of the framework for water governance, it is necessary to look at the meaning of this term and the history of its use. Water governance refers to both informal and formal methods of addressing the challenges of water management at local, regional and national levels by involving different users (Cooley et al., 2013). In the 2000s, most works in water governance were carried out at local and regional levels, but the emergence of challenges in terms of climate, 
shortages in supply, security and the presence of big multi-national companies, meant that water governance issues became global. This framework is a function of: I. resource availability in society, 2. arrangements for access to water, and 3. outcomes for various uses including domestic, irrigation and ecosystem services in the studied villages.

The framework illustrates how linkages between resources and outcomes are determined by the actors (youth) and agents, daily processes and practices and arrangements. It helps us to understand how youth involvement in water resource management works. The changes from different uses may lead to changing patterns of resource availability and arrangements for access, hence affecting the outcomes. In this framework, the youth is a resource that through different processes and outcomes, could constitute the key component of water source management. The GRR provides opportunities for the detailed study of water governance at the local level. We used this framework to trace interaction among the 3 parameters: the availability of productive resources accessed by youth, various arrangements (mainly institutions at the local and central government levels) and its influence on access to water (for different uses - outcomes) in the study villages. This framework corresponds to water for sustainable protection of water sources, water quality and aquatic systems as well as water for sustainable food production and rural development themes of the 1992 Dublin conference on water and the environment. Solid lines in the framework indicate linkages between parameters, a dotted arrow indicates feedback and light arrows indicate mediation. This is elaborated diagrammatically in Figure I below.

We reviewed the main productive resources accessed and owned by youth as one of key actors/agents, as well as the arrangements and processes in the conservation of water sources in the study villages. The review aimed to increase the understanding of their role in water management

\subsection{Productive resources}

The land resources in the study villages together with water from the GRR support livelihoods through fishery stocks, agriculture and ecosystem services - wildlife and grazing habitats that are used beyond national boundary. Degradation of water sources caused by different users including high livestock and human population as well as inefficient land use play a substantial role in the arrangement as well as availability of water or outcomes for different uses. 


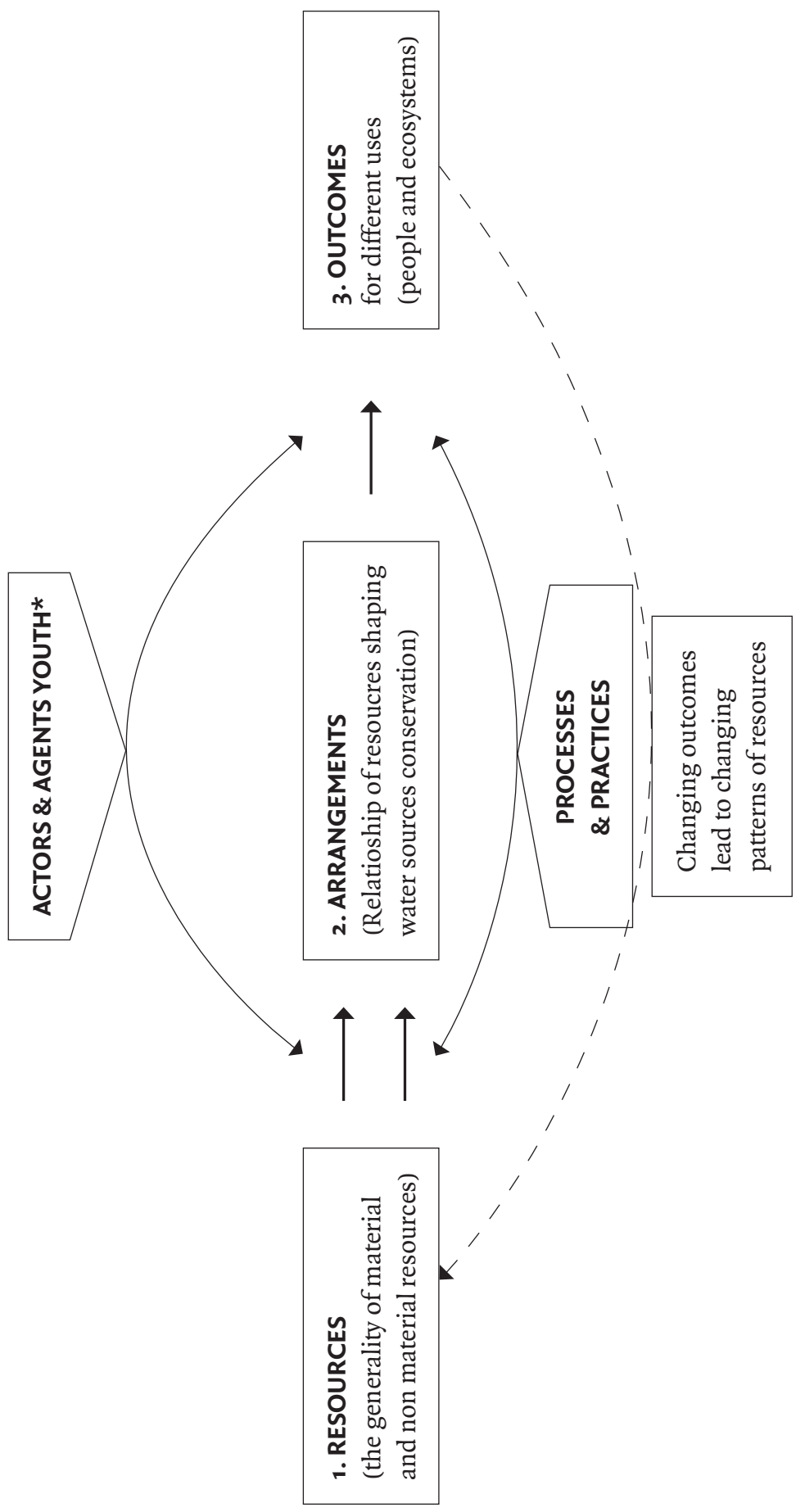

Figure 1: Water governance framework * Modified from Franks et al. (2013). 


\subsection{Arrangements}

There are many institutions in the GRR responsible for the conservation of natural resources. Some of these institutions also have socio-economic influence in the study villages. For example, the Tanzania Electric Supply Company (Tanesco) is responsible for the production and distribution of electricity in Mtera dam; religious organizations, on the other hand have a role in water supply and social services; the RBWO provides the platform for coordinating and guiding the development of water resources among different uses, while Iringa District coordinates Wards and Villages in rural developments including fishery resources from Mtera dam. International Non Governmental Organisations such as the Worldwide Fund for Nature (WWF) and Wildlife Conservation Society (WCS) facilitate and assist communities in natural resource conservation (MNRT and Ministry of Foreign Affairs Denmark, 2003). From the above description, it is obvious that in these two villages different stakeholders are involved in the management and conservation of water resources (URT, 20I0).

\subsection{Outcomes}

Water from different sources in the study villages is used for different purposes including domestic, agriculture, livestock, fishing and electricity production. Figure 2 shows that the two institutional (hydrological as well as administrative) structures differ and operate differently. While most of the water sources and natural resources are dealt with within the administrative structures, water flow is regulated by hydrological institutions. Effective water source management requires full integration of both institutions because water is a cross-cutting issue. However, the mechanism of facilitating lateral communication between the two institutions is inadequate (Ramsar Convention Secretariat, 2008). In the study villages, there is access to productive resources and therefore water access and use is affected by arrangements drawn up by these institutions and other stakeholders (actors/agents) in the villages.

For instance, district and village councils formulate by-laws and implement them with the aim of regulating access to natural resources by various users (Ramsar Convention Secretariat, 2008). Iringa District Council (2013) indicates there is poor access to clean water in the study villages where boreholes are the main sources of water. To improve the management of water in rural areas, the district council introduced Village Water Committees (VWCs), Water User Associations (WUAs) and Village Water Fund (VWF) in some selected villages. 


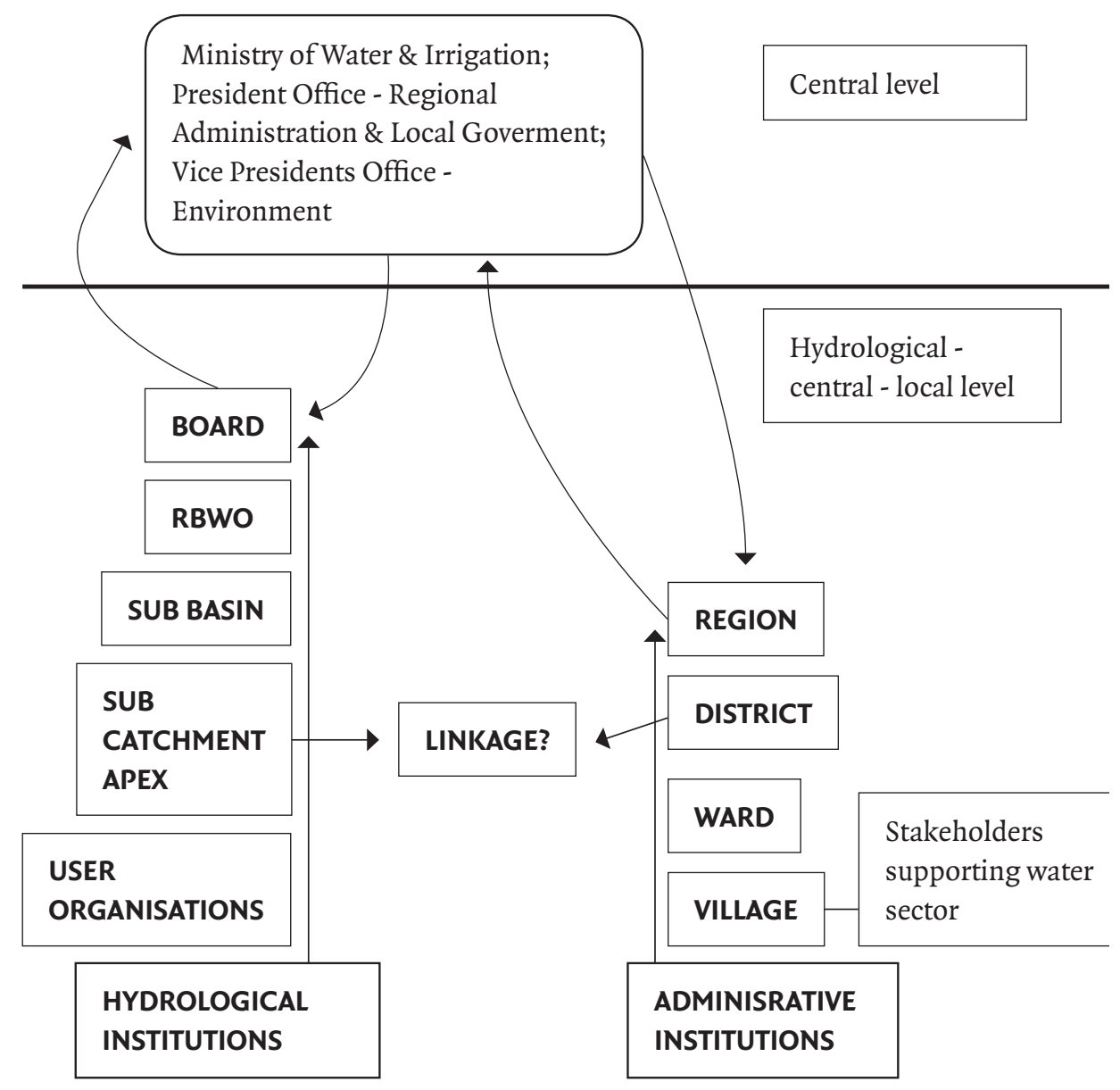

Figure 2: Institutions for water management in the GRR.

\section{Methodology}

3.1. The study area

The GRR is one of the focal areas for transforming the national economy through the Southern Agricultural Growth Corridor of Tanzania (SAGCOT), hydro-energy production and tourism development. The GRR covers $47 \%$ of, and contributes $15 \%$ of Average Annual flow to, the Rufiji Basin which is the largest and the most important basin in the country (URT, 20I0). A number of interventions including water governance at the local and integrated basin level have been piloted in this area (RBWO, 20II; Sokile et al., 2003; Sosovele and Ngwale, 2002). Additionally, the 2012 national census categorized the district as having a young population with an estimated $22.9 \%$ aged between 20 and 34 years (NBS, 20I4). This was the base for selecting this study area, and the findings will strongly inform society and policy makers to act upon what has been suggested 
accordingly. Moreover, other researchers may wish to replicate this study to other areas with a similar environment.

The GRR area was divided between upper and lower zones in order to include different socio - economic and ecological conditions. From each zone, one village was selected to maximize variability according to the distance from the GRR of youths who relied on the river for water. In the upstream zone (Kihanga) and the downstream zone (Migoli) villages were selected (Figure 3) - and surveys were carried out between May 2016 and February 20I7. The prevalent livelihood activities along the GRR floodplains include hydro-electric production and fishing in Mtera and bottom valley agriculture locally termed as "vinyungu" (Ikingura and Akagi, 2003; Sosovele and Ngwale, 2002).

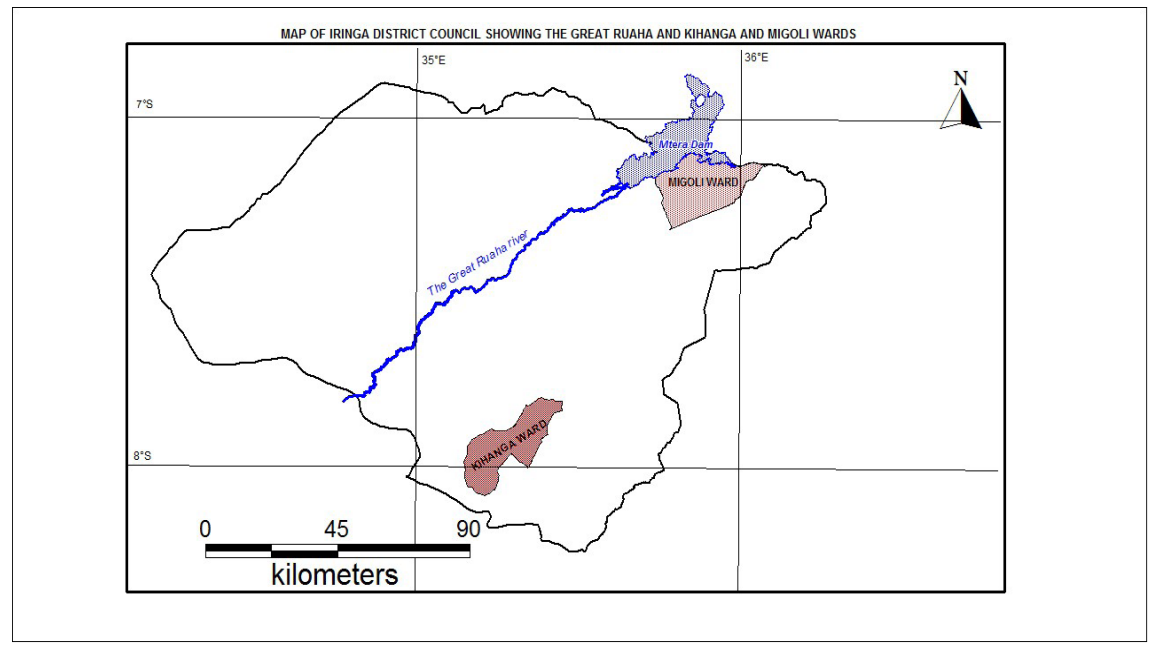

Figure 3: The location of the Kihanga and Migoli Wards / Villages in the GRR, Iringa District.

\subsection{Sample selection}

The target population comprised of youths living in the area. The sample size involved $15 \%$ of the youths in the 1,073 households of the two selected villages (Kihanga and Migoli) in Iringa District. A simple random sampling technique was used to select respondents. We considered youths whose data were in the village registry books (NBS, 20I4) because this was the only means of ascertaining the actual number of youths living in the study villages as daily rural - urban migration is a common phenomenon. The final sample size consisted of I6I youth respondents aged between I5 and 34 .

\subsection{Data collection}

Different techniques were used to gather both primary and secondary data. A literature review was used to gather secondary data from web resources, reports, journals, books and various policy documents from RBWO, District council and WWF - Ruaha water program. These data focused on water management and key productive resources 
of the study villages. The primary data were obtained through a Participatory Rural Appraisal (PRA) as a standard social survey, a tool that combines in-depth interviews and checklists of prepared questions.

Questionnaires were prepared and tested before being used for collecting socio-economic and water information from the youths within the households. Field observation and personal communication were used to complement data that could not be obtained from youths within households. FGD and in-depth interviews were used to gather primary qualitative data to supplement data that could not be obtained through household surveys. This was integrated into methodological design for some of the specific challenges encountered by youths in the conservation of water sources in the areas. Two focus group discussions were conducted; one at each village with 7-Io youth participants. During the FGD, we discussed the youth and their practices regarding water sources, supply and strategies.

The transect walk was conducted in the 8 randomly selected sites to observe any possible youth involvement in the water source conservation and water supply. Each session took at least I-2 hours to cover e.g. means used, frequency of fetching, etc. Photos were taken followed by notes. In addition, four in-depth interviews involving key informants (Regional Commissioners' Office, RBWO, District Council and Village leaders) were conducted.

\subsection{Data analysis}

Descriptive statistics and cross tabulation using SPSS version 20 was used in the analysis of the quantitative data while Template method ${ }^{\mathrm{I}}$ Brooks and King, (2014) was used in the analysis of qualitative data. Results were displayed in the tables and figures.

\subsection{Limitation of the study}

Despite seeking consent, the use of personal observation to capture events as they happen had limitations in Migoli village as some of the youth resisted having their pictures taken. This is because they feared that their negative actions would be reported to the authorities especially on issues related to school dropouts, degradation of dam banks by ox-cart and fetching of water which is not safe. However, to make this study reliable and to encourage the youths to cooperate, we informed them that their names will not appear in any data that is made publicly available and the information they provide would be used purely for research purposes.

I This method involves developing codes which summarize themes identified by the researcher as important in the data set and organize them in a meaningful and useful manner based on the content of participant interview scripts. 


\section{Results and discussion}

This section presents and discusses the results under each research question articulated above.

4.1. Demographic and socio-economic characteristics in the study villages

4.1.1. Distribution of respondents by sex

It was observed that respondents in the study villages were $50.9 \%$ female and $49 . \mathrm{I} \%$ male. The distribution was $58.9 \%$ female and $4 \mathrm{I} . \mathrm{I} \%$ male in Migoli and $59.2 \%$ male and $40.8 \%$ female in Kihanga. The results show that there were more female respondents than males in Migoli village while in Kihanga village, male respondents' responses outnumbered those of female respondents. Two factors might contribute to this situation: first most male youths in Migoli village are fishermen, during the survey most of them were not at home, thus increasing the percentage of female youth who were easily found at home in this village. Second is the influence of the Hehe in Kihanga village that restricts female youths from talking/sharing opinions with an outsider before seeking permission from elders/parents - thus more male youths were available.

The age range of the respondents in the study area is between 15 and 34 years. Most of the respondents (29.2\%) belong to the range ig to 22 years as is shown in Table I.

\begin{tabular}{|c|c|c|c|}
\hline \multirow[b]{3}{*}{ Group size (age in years) } & \multicolumn{2}{|l|}{ Ward / Village name } & \multirow{2}{*}{$\begin{array}{l}\text { Total } \\
\mathbf{N}=\mathbf{r} 6 \mathbf{I}\end{array}$} \\
\hline & Migoli n=9o & Kihanga $n=7 \mathbf{I}$ & \\
\hline & $\%$ & $\%$ & $\%$ \\
\hline I5-I8 & 0.0 & $\mathrm{I} .4$ & 0.6 \\
\hline I9-22 & 27.8 & 31.0 & 29.2 \\
\hline $23-26$ & 28.9 & 26.8 & 28.0 \\
\hline $27-30$ & 25.6 & 29.6 & $27 \cdot 3$ \\
\hline $3 I-34$ & I7.8 & II. 3 & I4.9 \\
\hline Total & 100.0 & 100.0 & 100.0 \\
\hline
\end{tabular}

Table 1: Age group of respondents. Source: Field survey (2016).

\subsubsection{Education}

The majority of the respondents in the study villages (about $81.7 \%$ and $54.4 \%$ in Kihanga and in Migoli respectively) attained primary or grade 7 education which is the compulsory level of education in Tanzania. 33.3\% of respondents in Kihanga and $18.3 \%$ in Migoli Village attained secondary education. But, it was observed that the number of youths with non-formal education was II.I\% in Migoli and o\% in Kihanga. The existence of a low percentage of youths with secondary and college education o\% in Migoli village relatively compared to Kihanga village could be due to the intensive involvement of youths in the fetching and selling of water. This was confirmed by one of the participants of the FGD who said:

"water vending business - fetching and selling has increased youth "drop out" from school where most of them rarely completed grade seven" 


\section{FGD participants in Migoli Village 26th September 2016}

\subsubsection{Socio-economic activities}

The results reveal that the majority of respondents (54.7\%) in the study villages depend on agriculture for food and income. Major crops grown reported by participants of the FGD and confirmed in the transect walk included maize, potatoes, tomatoes, green peas and beans - most of them grown on the valley bottoms called "vinyungu" during the dry season. These results are similar to those of a study by Magembe, (2007) which shows that "vinyungu" dominates dry season economic activities in Iringa region and does affect most of sources of water (Figure 4-A). Another non-farm activity was water vending (Figure 4-B). Other socio-economic activities' contribution such as small business, fetching and supply of water for cash and fishing were 2 I. $1 \%, 7.5 \%$ and $6.2 \%$ respectively.

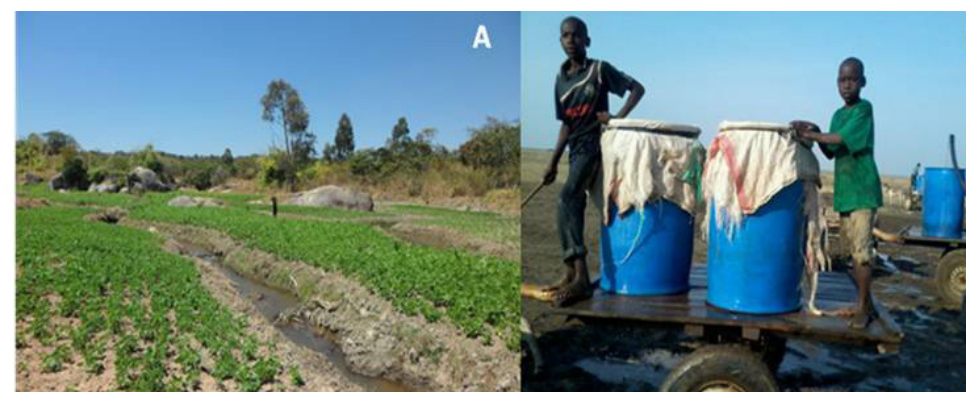

Figure 4: Socio-economic activities affecting sources of water: A. Kinyungu grown beans at Kihanga Village; B. Youth riding ox-cart with two water barrels ready for vending at Migoli Village.

Results presented in Table 2 reveal that of the respondents who are involved in the agricultural activities $59.5 \%$ are male and $50.0 \%$ female. In the category of small business, however, it is $30.5 \%$ female and II. $4 \%$ male. Although, female youths have designated roles on transplanting the seedlings and picking tomatoes on the farms, these findings are consistent with a study by Mumuni and Oladele (20I6) which showed among rice farmers in Ghana, women are prevented from engaging in agriculture if the outcome proved to have more financial benefits. 


\begin{tabular}{|c|c|c|c|}
\hline & \multicolumn{2}{|l|}{ Sex of the respondent } & \multirow{2}{*}{$\begin{array}{l}\text { Total } \\
\mathbf{N}=\mathbf{I} 6 \mathbf{I}\end{array}$} \\
\hline & Male $\mathrm{n}=79$ & Female $\mathrm{n}=82$ & \\
\hline & $\%$ & $\%$ & $\%$ \\
\hline Agriculture & $59 \cdot 5$ & 50.0 & $54 \cdot 7$ \\
\hline $\begin{array}{l}\text { Small business (shops, food } \\
\text { vending) }\end{array}$ & II.4 & 30.5 & $2 \mathrm{I} . \mathrm{I}$ \\
\hline Civil servant (employed) & 2.5 & 0.0 & $\mathrm{I} .2$ \\
\hline Animal husbandry & 3.8 & I. 2 & 2.5 \\
\hline $\begin{array}{l}\text { Fetching and supply of water } \\
\text { for cash }\end{array}$ & 7.6 & $7 \cdot 3$ & $7 \cdot 5$ \\
\hline Fishing & II. 4 & I. 2 & 6.2 \\
\hline Other & 3.8 & 9.8 & 6.8 \\
\hline Total & 100.0 & 100.0 & 100.0 \\
\hline
\end{tabular}

Table 2: Distribution of economic activities by gender. Source: Field survey (2010).

4.2. Youth access to productive resources and water management and use

4.2.1. The sources of water

The main sources of water identified in the two villages were: the dam in Migoli $63.3 \%$ and a small number of shallow wells in Kihanga, I. $4 \%$. The findings show the use of water from boreholes was $42.3 \%$ in Kihanga and $7.8 \%$ in Migoli especially during the rainy season. This could be explained by variation in water availability between Kihanga Village located on the upstream with a relatively high water table but the village is located far from the GRR, while Migoli is dry with a low water table but close to the GRR/ dam. Other sources of water identified included small rivers/streams $(26.7 \%$ in Migoli and $23.9 \%$ in Kihanga). The improved wells accounted for $2.2 \%$ of supply in Migoli and $26.8 \%$ in Kihanga while piped scheme and rainwater harvesting accounted for $5.6 \%$ in Kihanga and $\% \%$ in Migoli.

Institutions and the availability of water have determined the nature of the water delivery technology used. For instance, we observed that while boreholes serve as main source of water (Figure 5-A), hand pumps were mainly used in the community standpipes in Kihanga village (Figure 5-B) while in schools energy or gravity piped technology was used. In areas with water shortages such as Migoli village, the use of an ox-cart and 3 tire-trolleys is common (Figure 5-C). These findings are consistent with a study conducted by Iringa District Council (2013) which shows the existence of different types of water sources and their delivery technology in the area. 


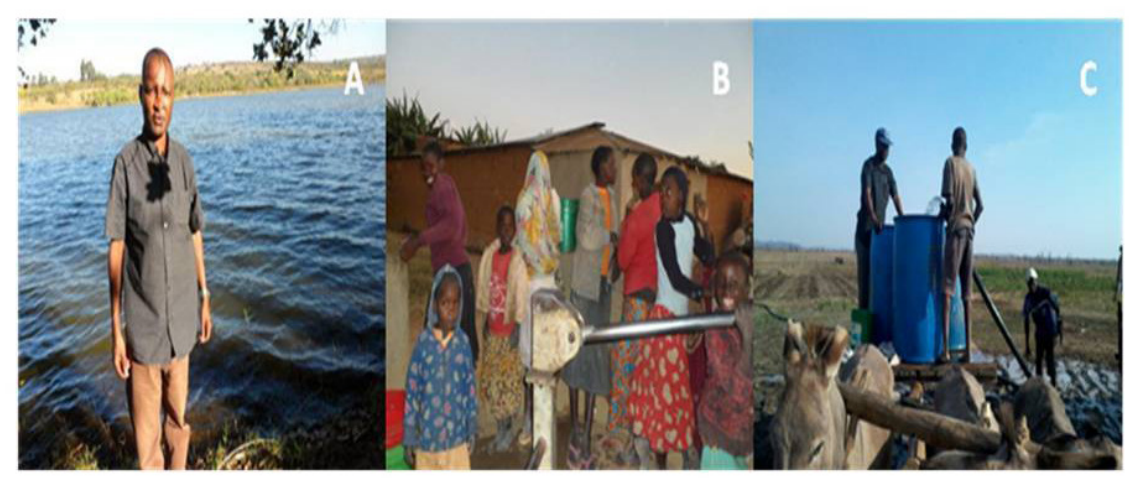

Figure 5: Main sources of water in the study villages: A. Borehole, B. Hand pump is the water major delivery technology in Kihanga village, C. Ox-cart is the main delivery technology in Migoli village.

\subsubsection{The main use of water}

The water from the sources has mainly been used for domestic purposes $(97.8 \%$ in Migoli and 95\% in Kihanga) while 2.2\% in Migoli and $4.2 \%$ in Kihanga has been used for irrigation and sustaining livestock. Water in the natural flow supports wildlife and electricity generation. Table 3 shows the distribution of the main productive resources owned by respondents in the two villages including 30.4\% farms, 2I.I\% domesticated animals, and $\mathrm{I} 6.8 \%$ houses.

\begin{tabular}{|c|c|c|c|}
\hline \multirow[b]{3}{*}{ Productive resource name } & \multicolumn{2}{|l|}{ Ward / Village name } & \multirow{2}{*}{$\begin{array}{l}\text { Total } \\
\mathrm{N}=\mathbf{I 6} \mathbf{I}\end{array}$} \\
\hline & Migoli $\mathrm{n}=90$ & Kihanga $n=71$ & \\
\hline & $\%$ & $\%$ & $\%$ \\
\hline House & 22.2 & $9 \cdot 9$ & I6.8 \\
\hline Farm & I4.4 & 50.7 & 30.4 \\
\hline Plot & 8.9 & 5.6 & 7.5 \\
\hline $\begin{array}{l}\text { Domesticated animals / } \\
\text { livestock }\end{array}$ & $\mathrm{I} 2.2$ & 32.4 & $2 \mathrm{I} . \mathrm{I}$ \\
\hline Oxcart & 4.4 & I.4 & $3 \cdot 1$ \\
\hline Three tire trolley & 2.2 & 0.0 & $\mathrm{I} .2$ \\
\hline Motor bike & 6.7 & 0.0 & $3 \cdot 7$ \\
\hline Other & I.I & 0.0 & 0.6 \\
\hline Not owning & 27.8 & 0.0 & $15 \cdot 5$ \\
\hline Total & 100.0 & 100.0 & 100.0 \\
\hline
\end{tabular}

Table 3: Major productive resources ownership. Source: Field survey (2016). 
Results show that the majority of the respondents own a land area of less than 5 hectares (94.4\% in Migoli and $100 \%$ in Kihanga). The major productive resource that was reported to have affected water source management efforts was livestock $(82.9 \%$ in Kihanga and $34.4 \%$ in Migoli). The farm location in the catchment has also affected water sources (II.I\% in Migoli and 8.6\% in Kihanga). These findings were also supported by participants of the FGD who reported that the custom followed by some parents of providing youths with land located in the catchment areas was said to have affected water sources particularly through intensification of bottom valley cultivation, hence affecting water supply in Kihanga Village (Figure 6).

"one of the focus group participant in Kihanga Village reported that customary land inheritance practices where elderly people passes land to youth which is located in the catchment has greatly contributed to the degradation of water source in this village because majority of vinyungu extend closer to the water sources facilitating soil erosion and siltation"

FGD participants in Kihanga village ist August 2016

We also observed during the transect walk that ox-carts and 3-tire trolleys have affected river and dam banks through trampling. The resultant effect is the supply of unsafe water to the households. The District Council report shows that water from shallow wells and boreholes is not safe (Iringa District Council, 2013) and this could be the possible source for unsafe water.

Dry season cultivation in the catchments in Kihanga Village (Figure 6-A) and in Mtera dam during the water recession (Figure 6-B) was found to have degraded most of the water sources in the study villages. Although respondents did not report this as a challenge, we observed in the transect walk that most of the stand pipes in Migoli Village were not functioning. This was consistent with the findings of water management issues in Rufiji Basin conducted by RBWO in $201 \mathrm{I}$ (Figure 6-C).

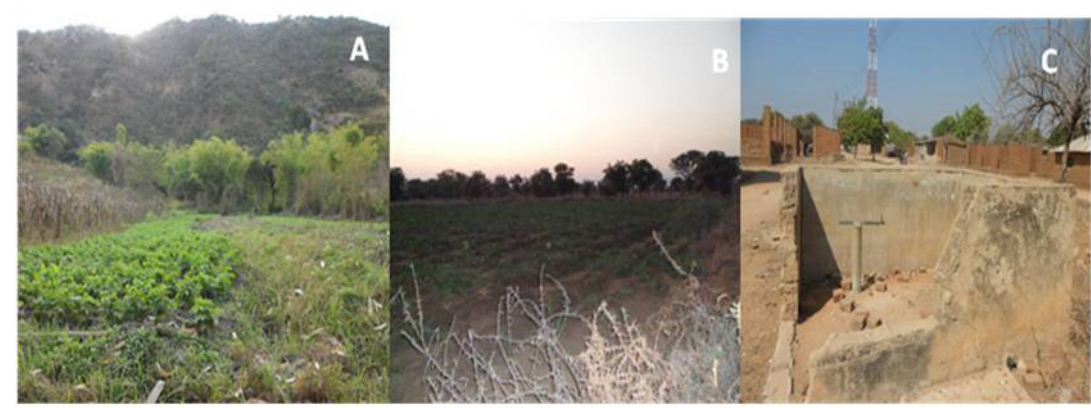

Figure 6: Challenges for water source management: A. Cultivation on the inherited land in the catchment "kinyungu" Kihanga village; B. Water melon cultivation in Mtera dam during dry season; C. Abandoned non functional stand pipe in Migoli village. 


\section{$4 \cdot 2 \cdot 3 \cdot$ Youth participation in the Village Water Committees (VWC)}

Despite the large size of the group, it was found that the youth, and particularly female youth, have had little or no direct influence on the decisions made by VWC on the management and use of water. The observed low involvement of community actors in water management is similar to the findings of Dungumaro and Madulu (2003) in a study of public participation in integrated water resources management. Results show that $2.4 \%$ of female and $6.3 \%$ of male respondents were members of the VWC. With regard to the involvement in the decision making on VWC activities, our findings highlight that $55.7 \%$ of the males and $63.4 \%$ of the females are not involved. Members of the VWC consider female contribution to have no influence on water because they do not own significant productive resources but also make less of a contribution in terms of labour related to infrastructural works. This could have been caused by an increased concentration of power in the hands of the elderly, thereby depriving the youth the opportunity to manage resources. It was also observed that only $13.4 \%$ of female respondents compared to I5.2\% of male respondents air their views in the VWC meetings. Narayan (I995) reported similar results that although development funded projects show significant beneficiary participation in achieving functional water systems, women were found to be less represented in most of the water projects in many parts of developing countries.

Moreover, results show that of the I4 members of the Village Natural Resources Committees (VNRCs), 28.6\% were female and 71.4\% were male indicating that male members heavily outweigh female members in terms of participation in natural resources management issues. When asked why they were not participating in the committees, women responded that they did not see any reason to do so because their contributions and suggestions to the committee had always been neglected. These findings are similar to the findings of a study of Cleaver (I995) on informal institutions for water resources management in Zimbabwe and Lusuva (2009) in Mkoji sub catchment Tanzania which show that despite higher levels of women involvement in fetching of water in many areas of Africa, the women rarely participate in the water resources management in Mkoji sub catchment of Tanzania.

Generally, we found less participation of female youth in VWC activities in both of the study villages. At household level, most of the youth who participated in FGD told us that male youths were given the second priority of using water after parents, compared to the females who were not given any particular priority when water was in short supply. When asked the reason for this, they briefly said that theirs is a culture in which a woman cannot use water for bathing or washing before a man/male.

In terms of amount of water used, findings reveal that $35.4 \%$ of the male and $41.5 \%$ of the female respondents used less than 50 litres of water in a day while $31.6 \%$ males and $30.5 \%$ females used between 60 and roo litres including drinking, cooking and personal hygiene. With respect to how respondents obtain the water they use, $59 \cdot 5 \%$ of male and $40.2 \%$ of female respondents obtained their water free of charge while $40.5 \%$ males and $59.8 \%$ of females bought water from vendors. These statistics are similar to results of a study by Lekunze (200I) on the role of youth in community water management projects 
in Cameroon which show between 40 and 60 litres of water is consumed daily in meeting household needs.

The findings show that $30.4 \%$ of males and $34 . \mathrm{I} \%$ female respondents decided how much water should be used in the household. Also respondents $(22.8 \%$ of males and $20.7 \%$ of females) could decide on the amount of water they use. When asked about the status of water from the existing sources, $45.6 \%$ of male and $30.5 \%$ of female respondents said water supply was in line with the average, while $30.4 \%$ of male and $40.2 \%$ of female respondents highlighted that the study villages encounter the short supply of water.

\subsection{The strategies used in the management of water sources}

Table 4 shows the main strategies used by youth in conserving water sources in the two villages studied. These strategies have been constructed based on two existing hydrological and administrative models. Accordingly, it has been established that the strategies used in Kihanga and Migoli villages differ depending on the availability of productive resources including land, livestock and mechanized equipment.

\begin{tabular}{|c|c|c|c|}
\hline \multirow[b]{3}{*}{ Practices } & \multicolumn{2}{|l|}{ Ward / Village name } & \multirow{2}{*}{$\begin{array}{l}\text { Total } \\
\mathbf{N}=\mathbf{I} 37\end{array}$} \\
\hline & Migoli n=66 & Kihanga $n=6 r$ & \\
\hline & $\%$ & $\%$ & $\%$ \\
\hline Tree planting & $4 \cdot 5$ & 39.4 & 22.6 \\
\hline Ban of human activities & $27 \cdot 3$ & 22.5 & 24.8 \\
\hline Treatment & 7.6 & 0.0 & 3.6 \\
\hline $\begin{array}{l}\text { Patrolling sources and fetching } \\
\text { water in the night }\end{array}$ & $37 \cdot 9$ & I6.9 & 27.0 \\
\hline High penalty to offenders & 0.0 & $9 \cdot 9$ & 5.1 \\
\hline Efficient / proper use of water & I0.6 & II. 3 & 10.9 \\
\hline Frequent cleaning & I2.I & 0.0 & 5.8 \\
\hline Total & 100.0 & 100.0 & 100.0 \\
\hline
\end{tabular}

Table 4: Strategies used by youth in water conservation. Source: Field survey (2010).

The main strategy used by the respondents for managing water sources for domestic use was patrolling of sources and fetching water in the night; $37.9 \%$ of respondents in Migoli and $16.7 \%$ in Kihanga villages used similar strategies. Other major strategies used include ban of human activities (used by $27.3 \%$ of respondents in Migoli and $22.5 \%$ in Kihanga), tree planting (39.4\% in Kihanga and $4.5 \%$ in Migoli) and efficient use of water (I0.6\% in Migoli and II. $3 \%$ in Kihanga). The proportions of youth that used tree planting was low (4.5\% in Migoli compared to $39.4 \%$ in Kihanga). The difference in adoption of tree planting could be attributed to low rainfall and high population of livestock which threaten tree survival rates in Migoli village. Water treatment was among the least $(3.6 \%)$ used strategy (7.6\% in Migoli and 0.0\% in Kihanga).

During the FGD, the majority of participants reported that "due to the benefits obtained from fetching and supplying of water for sale, the importance of patrolling sources 
of water and fetching of water during the night has been developed over dry season among the youth". The observation was confirmed during the transect walk which was conducted on 6th August, 2016 in the night at I.00 am (Figure 7-A) and 5.00 am (Figure 7-B).

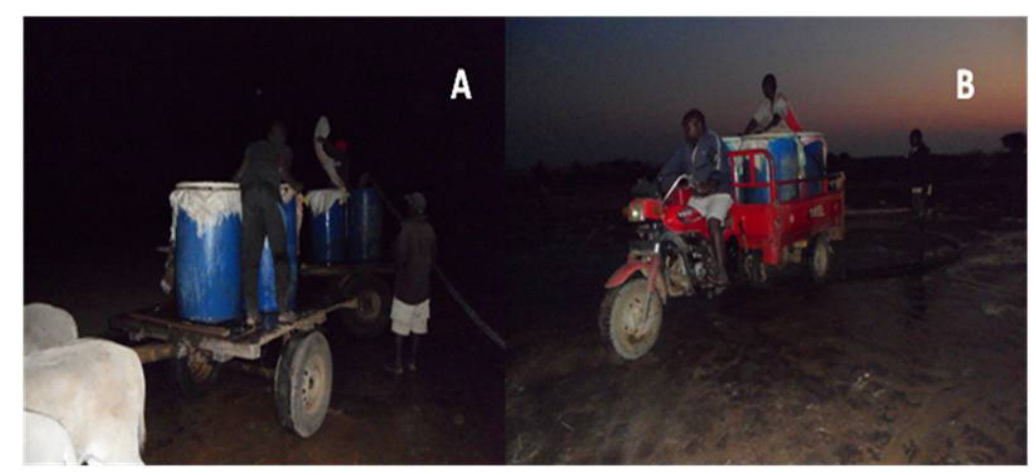

Figure 7: Fetching of water during the night: (A) ox-cart and motorized 3 tire-trolleys (B) in Migoli village.

\section{Conclusion}

This study aimed to understand the role of the youth in water source management and determined the various strategies used in Kihanga and Migoli Villages in Iringa District, Tanzania. Results show that youths possess considerable potential and play a key role in water management in the GRR. The findings together with methods used could be replicated to other areas as they provide opportunities for studies of water governance at the local level. However, sustainability is threatened by low levels of participation in VWC and intensive agricultural activities in water sources. To address these challenges, the youth should effectively be engaged and integrated into VWC/WUAs.

It has been noted that shallow wells, boreholes, rivers and dams are the main sources of water in the study villages. Livestock and land located in the catchment areas are the major productive resources reported to have affected water source conservation efforts. The study reports that female respondents were few among members of the Village Natural Resources Committee, and were not participating fully in water source conservation activities. Although youths maintained a positive attitude towards water source management, their participation in the village water committees was inadequate.

As the population of young people in Tanzania is projected to increase, and given the size of the current age group o-17 year (50.1\%) in 2012, we recommend several measures to be taken into consideration. First, the management system of water resources through VWC need be transformed to integrate more youth to be among the members of the committees under the administrative institutions. Second, because the fetching of water from the Mtera dam seems to continue, alternative permanent pumping stations along dam shores need to be established to reduce trampling effect on water sources by ox-cart and/or 3-tire trolleys. Third, Integrated Land Use Land Cover in the present institutional set up, legislation is needed. Finally, both hydrological and administrative 
institutions need to be linked, at least at the level of the District Council to remove existence of parallel institutions for water resources management.

\section{Acknowledgements}

This study was funded by the Flemish Inter-university Council and Mzumbe University through a VLIR-UOS Project. Authors are also very grateful to the District Executive Director of Iringa who allowed us to conduct this study in their area. Further, we wish to thank youth and village leaders of the study areas for participating in this study.

\section{References}

Agbor, J., Taiwo, O. and Smith, J. (2012). Sub-Saharan African's Youth Bulge: A demographic dividend or distance? Brookings Institute, Washington, USA.

Akkerman, M., Khanh, N. T., Witter, M. and Martine. (2013). Emergence of Integrated Water Resources Management: measuring implementation in Vietnam.

Brooks, J. and King, N. (2014). Doing Template Analysis: Evaluating an End of Life Care Service. Sage Research Methods Cases. doi.org/10.4135/978144627305013512755.

Cleaver, F. (1995). Women and Water Resources: Continued Marginalisation and New Policies. Gatekeeper series No. 49. International Institute for Environment and Development, London.

Cooley, H., Ajami, N., Ha, Mai-Lan., Srinivasan, V., Morison, J., Donnely, K. and Christian-Smith, J. (2013). Global water governance in the 21st Century. Pacific Institute, Oakland California, USA.

Creswell, J. and Clark, V. (2007). Designing and Conducting Mixed Methods Research. Australian and New Zealand Journal of Public Health, 31, 388. doi:10.11nI/j.1753-6405.2007.00096.x.

Dungumaro, E. W. and Madulu, N. F. (2003). Public participation in integrated water resources management: The case of Tanzania. Physics and Chemistry of the Earth, 28(20-27), I009-Ior4. doi.ro.ror6/j. pce.2003.08.042.

Franks, T., Cleaver, F., Maganga, F. and Hall, K. (2013). Environment, Politics and Development Working Paper Series Department of Geography, King's College London Evolving outcomes of water governance arrangements: Smallholder irrigation on the Usangu plains, Tanzania.

Ikingura, J. R. and Akagi, H. (2003). Total mercury and methylmercury levels in fish from hydroelectric reservoirs in Tanzania. The Science of the Total Environment, 304: 355-368.

Iringa District Council. (2013). Socio-economic Profile. Iringa, Tanzania.

Khedun, P. (2012). Importance of youth involvement in water resources management. Retrieved from http://phys.org/news/20I2-I2-america-young-scientist-crafts-purify.html\#jCp

Lekunze, R. N. (200I). Assessing stakeholder participation in Integrated Water Resource Management. The role of Youth in Community Water Management Projects in Cameroon. MSc. Thesis Lund University, Sweden.

Logo, M., Koppen, van, and Kpr, A. (2014). Ensuring Integrated Water Resource Management in Tanzania Benefits All. International Journal of Water Resources Development, 30(76). doi.10.1080/079006.

Lusuva, E. A. (2009). An Assessment of Gender Mainstreaming in Water Resources Management: A Case of Study of Mkoji Sub Catchment in Usangu Plains, Tanzania. MSc. Dissertation, University of Zimbabwe.

Magembe L. (2007). Transformation of Valley-bottom Cultivation and its Effects on Tanzanian Wetlands: A case study of Ndembera Wetland Area in Iringa Region. MSc. Thesis, University of Florida.

Ministry of Foreign Affairs, Denmark and Ministry of Natural Resources and Tourism (2010). Annual Sector Review for Environmental Sector Programme Support. Dar es Salaam, Tanzania [Unpublished].

Ministry of Water and Irrigation. (2010). Integrated Water Resources Management and Development Project for the Rufiji River Basin, Inception Report, Volume I, developed by WREM International Inc., Atlanta, Georgia, USA (Vol. I). Atlanta, Georgia, USA. 
MNRT. (2007). The Wildlife Policy of Tanzania. Dar es Salaam, Tanzania [Unpublished].

Ministry of Natural Resources and Tourism and Ministry of Foreign Affairs Denmark. (2003). Sustainable Wetlands Management (2004-2009). Ref.No.ro4.Tanzania.I.MFS.23. Dar es Salaam, Tanzania. [Unpublished].

Movik, S., Mehta, L., van Koppen, B. and Denby, K. (2016). Emergence, interpretations and translations of IWRM in South Africa. Water Alternatives, 9(3): 456-472.

Mumuni, E., and Oladele, O. I. (20I6). Access to livelihood capitals and propensity for entrepreneurship amongst rice farmers in Ghana. Agriculture \& Food Security, I-II. doi.ro.1186/s40066-015-0049-X.

Narayan, D. (1995). The Contribution of Peoples Participation 'Evidence from 121 Rural Water Supply Projects' (p. I08). Washington DC: World Bank.

NBS. (2014). The 2012 Population and Housing Census: Basic Demographic and Socio-Economic Profile. National Bureau of Statistics. Dar es Salaam, Tanzania [Unpublished].

Ramsar Convention Secretariat. (2008). Field notes for Great Ruaha River case study. Gland, Switzerland [Unpublished].

RBWB. (2015). Environmental and Social Impact Assessment Lugoda Dam and Maluluma Hydropower on Ndembera River Environmental and Social Impact Assessment Report (Vol. I). Iringa, Tanzania.

RBWO. (20II). Water management issues in Rufiji Basin, Iringa, Tanzania.

Sokile, C. S., Kashaigili, J. J. and Kadigi, R. M. J. (2003). Towards an integrated water resource management in Tanzania: the role of appropriate institutional framework in Rufji Basin. Physics and Chemistry of the Earth, Parts A/B/C, 28(20-27): 1015-1023.

Sokile, C. S., Mwaruvanda, W. and Koppen, B. Van. (2005). Integrated Water Resource Management in Tanzania: interface between formal and informal institutions. In African Water Laws: Plural Legislative Frameworks for Rural Water Management in Africa (pp. 26-28).

Sosovele, H. and Ngwale, J. (2002). Socio-economic root causes of the loss of biodiversity in the Ruaha catchment area. Dar es Salaam, Tanzania.

SMUWC. (200I). Final Report - Water resources. doi.ro.IoI7/CBO9781107415324.004

SEI. (20II). Ecosystems, Development and Climate Adaptation: Improving the Knowledge base for policies, planning and management. Final Report for Tanzania Study.

Turpie, J. K., Ngaga, Y. M. and Karanja, F. K. (2005). Catchment Ecosystems and Downstream Water: The value of water resources in the Pangani Basin, Tanzania. Lao PDR. IUCN Water, Nature and Economics Technical Paper No. 7, IUCN - The World Conservation Union, Ecosystems and Livelihoods Group Asia.

United Nations. (2015). Population Facts: Youth population trends and sustainable development.

UNFPA. (2015). The 2014 State of the World Population Report.

UNICEF. (2011). Regional Overview: Youth in Africa.

URT. (2007). National Youth Development Policy. Dar es Salaam, Tanzania.

URT. (2010). Ministry of Water and Irrigation Water Sector Status Report 2010. Dar es Salaam, Tanzania [Unpublished].

WRC. (2005). Developing a method for determining the environmental water requirement for non-perennial systems. Centre for Environmental Management University of the Free State, South Africa. 